\title{
Akseptabilitas Paket Pelatihan Kesadaran Multikultural bagi Mahasiswa
}

\author{
Narno $^{1}$, Blasius Boli Lasan ${ }^{1}$, Nur Hidayah ${ }^{1}$ \\ ${ }^{1}$ Bimbingan dan Konseling-Universitas Negeri Malang
}

\begin{tabular}{l} 
INFO ARTIKEL \\
\hline Riwayat Artikel: \\
Diterima: $15-07-2019$ \\
Disetujui: 11-02-2020 \\
\hline
\end{tabular}

Kata kunci:

training package; multicultural awareness; college student;

paket pelatihan;

kesadaran multikultural; mahasiswa

\begin{abstract}
ABSTRAK
Abstract: The purpose of this study was to produce a product in the form of a multicultural awareness training package for students who meet the criteria for product acceptance that covers aspects of usability, feasibility, accuracy and attractiveness. This procedure of research and development uses a research model and development of Borg \& Gall. The test results showed that the guidance and counseling expert obtained an index of validity of 0.77 (moderate), material experts obtained an index of validity of 0.89 (high), experts in learning media obtained an index of validity of 0.90 (high), and prospective users obtained validity index of 0.89 (high), so it can be concluded that the product of multicultural awareness training package has met the criteria for product acceptance, so it is feasible to be used in training activities.
\end{abstract}

\begin{abstract}
Abstrak: Tujuan penelitian ini ialah menghasilkan produk berupa paket pelatihan kesadaran multikultural bagi mahasiswa yang memenuhi kriteria keberterimaan produk yang mencangkup aspek kegunaan, kelayakan, ketepatan dan kemenarikan. Prosedur penelitian dan pengembangan ini menggunakan model penelitian dan pengembangan Borg \& Gall. Hasil pengujian menunjukkan, ahli bimbingan dan konseling diperoleh indeks validitas sebesar 0,77 (sedang), ahli materi diperoleh indeks validitas sebesar 0,89 (tinggi), ahli media pembelajaran diperoleh indeks validitas sebesar 0,90 (tinggi), dan calon pengguna diperoleh indeks validitas sebesar 0,89 (tinggi) sehingga dapat disimpulkan produk paket pelatihan kesadaran multikultural telah memenuhi kriteria keberterimaan produk sehingga layak untuk digunakan dalam kegiatan pelatihan.
\end{abstract}

\author{
Alamat Korespondensi: \\ Narno \\ Bimbingan dan Konseling \\ Universitas Negeri Malang \\ Jalan Semarang 5 Malang \\ E-mail: narno.lalanlangi@yahoo.co.id
}

Keragaman budaya merupakan konteks yang perlu dipelajari (Zapata-Barrero, 2018) sebagai upaya dalam memahami, menerima, dan menentukan sikap di tengah keberagaman yang ada. Mempelajari budaya dapat memberikan pemahaman tentang keberagaman budaya, yang tidak hanya didasarkan atas perbedaan suku maupun etnis semata, melainkan pada keseluruhan aspek budaya seperti nilai, norma, pandangan hidup, keadaan fisik, usia, gender, orientasi seksual, ras atau etnis, bahasa, sosial ekonomi, dan lokasi geografis (Ivey, 2010). Berbagai aspek tersebut menjadi dasar perbedaan yang akan membentuk dan memengaruhi identitas diri dalam interaksi sosial dengan orang lain. Interaksi sosial antar individu maupun kelompok yang berbeda secara budaya merupakan bentuk perjumpaan budaya atau kontak budaya. Kontak budaya ialah pusat multikulturalisme (Modood, 2017), yang tidak jarang akan mengubah Ward \& Geeraert (dalam Vora et al., 2018) membentuk dan menghasilkan budaya baru bagi orang-orang didalamnya. Fenomena multikultural tidak hanya terjadi pada lingkungan masyarakat secara luas, namun juga terjadi pada jenjang perguruan tinggi. Keberagaman budaya merupakan suatu keindahan jika mahasiswa menghayati multikultural sebagai kebersamaan dalam perbedaan, namun berbeda halnya jika penghayatan perbedaan sebagai alasan untuk tidak bersama, dimana akan terjadi konflik sosial dalam hubungannya dengan orang lain.

Terdapat tiga komponen utama kompetensi multikultural yang dapat menjadi modal dalam menjalani kehidupan di tengah keberagaman dan menjadi senjata dalam menangani isu-isu multikultur, diantaranya adalah kesadaran multikultural, pengetahuan multikultural, dan keterampilan multikultural (Ratts \& Pedersen, 2014). Peranan utama terletak pada komponen kesadaran multikultural sebagai dasar kuat bagi mahasiswa dalam memahami dan menyadari bahwa budaya yang dimiliki akan memengaruhi perkembangan diri serta cara pandang terhadap diri dan orang lain. Kesadaran multicultural merupakan kemampuan untuk mengetahui, memahami dan menyadari adanya keberadaan budaya dan posisinya dalam konteks membina hubungan sosial yang efektif (Hambali, 2016). Kesadaran multikultural akan menjadi dasar perwujudan sikap dan perilaku yang sesuai, serta menuntun kita dalam memahami orang lain yang berbeda budaya secara penuh. Hal tersebut diperkuat dengan pendapat Moule (2012) bahwa langkah pertama menuju kompetensi budaya melibatkan pengembangan kesadaran tentang caracara dimana budaya berbeda dan menyadari bahwa perbedaan-perbedaan ini dapat memengaruhi proses pembelajaran. Jadi, 
dapat dijelaskan bahwa komponen utama yang menjadi dasar dalam memahami diri orang lain ialah kesadaran multikultural, sebaliknya rendahnya tingkat kesadaran multikultural dapat menjadi salah satu faktor timbulnya konflik di lingkungan sosial.

Bukan perkara yang mudah untuk mencapai tingkat kesadaran multikultural yang tinggi. Jackson \& Wasson (dalam Rohiman \& Pamuji, 2017) menjelaskan untuk mencapai kesadaran multikultural, seseorang terlebih dahulu harus mengenali budayanya sendiri. Saat individu belum mampu mengetahui atau mengenali dirinya sendiri maka sangat sulit baginya untuk memahami orang lain dari sudut pandang orang tersebut. Adanya kesadaran multikultural menghantarkan konselor pada cara pandang, mindset, persepsi, dan sikap yang sesuai. Perspektif yang digunakan untuk menilai sebuah tindakan, sikap dan perilaku tidak hanya menggunakan ukuran konselor secara pribadi, namun juga menggunakan ukuran atau frame dari konseli. Sebaliknya rendahnya tingkat kesadaran multikultural mahasiswa akan meningkatkan potensi terjadinya konflik, hal ini disebabkan ketidakpahaman dan ketidaktahuan dalam menyikapi berbagai perbedaan. Dengan demikian, sangat penting untuk dilakukan upaya baik itu melalui pembelajaran di kelas maupun program pelatihan yang bertujuan meningkatkan kesadaran multikultural mahasiswa.

Beberapa penelitian telah dilakukan sebagai acuan dalam mendukung asumsi pentingnya pengembangan kesadaran multikultural bagi mahasiswa BK, diantaranya hasil penelitian Permatasari, Bariyyah, \& Indrati (2017) menyarankan perlu dilakukan sebuah penelitian eksperimen atau pengembangan dengan teknik tertentu untuk meningkatkan tingkat kesadaran multikultural mahasiswa. Selanjutnya Gumilang (2015) dan (Rohiman \& Pamuji (2017) menyarankan perlunya pengembangan suatu model dalam meningkatkan kesadaran multikultural mahasiswa. Mengingat urgensi kesadaran multikultural bagi mahasiswa maka perlu dilakukan upaya sebagai langkah pencegahan menurunnya tingkat kesadaran multikultural mahasiswa dengan mengembangkan sebuah program pembelajaran sistematis yang bermuara pada peningkatan kesadaran multikultural mahasiswa. Perancangan program yang sistematis dan terarah dapat diwujudkan dalam bentuk paket pelatihan. Paket pelatihan menspesifikasi pengalaman belajar dalam bentuk penstrukturan kegiatan pembelajaran yang kaya dengan berbagai variasi, sehingga dapat memberikan efek pengiring yang efektif untuk mencapai tujuan.

Adapun model pelatihan yang diterapkan untuk mengembangkan kesadaran multikultural mahasiswa ialah The Purnell Model for Cultural Competence (Purnell, 2002). Model Purnell merupakan sebuah model yang berorientasi pada budaya, yang menyediakan kerangka pengorganisasian holistik dengan pertanyaan spesifik dan format untuk menilai budaya (Purnell, 2005). Adapun aktivitas dalam pelatihan terbagi menjadi tiga, yaitu presentasi, praktik, dan dialog. Program pelatihan ini akan membimbing mahasiswa dalam pengumpulan data, serta mendapatkan pandangan yang komprehensif tentang orang lain dan kehidupan mereka sehingga berujung pada peningkatan kesadaran multikultural mahasiswa.

\section{METODE}

Penelitian ini termasuk jenis penelitian dan pengembangan (research and development). Prosedur pengembangan paket pelatihan kesadaran multikultural dalam penelitian ini mengadaptasi dari langkah-langkah penelitian pengembangan yang dikembangkan oleh Borg \& Gall (1983) dengan mengambil langkah pengembangan hingga tahapan ke lima, yaitu uji validasi produk yang dilakukan oleh ahli BK, ahli materi, ahli media pembelajaran, dan calon pengguna. Instrumen pengumpulan data yang digunakan dalam penelitian dan pengembangan ini berupa angket uji ahli dan skala kesadaran multikultural.

Teknik analisis data dalam penelitian dan pengembangan ini meliputi analisis data kuantitatif dan analisis data kualitatif. Kedua data tersebut akan dianalisis secara sistematis dan mendetail sehingga mendapatkan hasil yang akurat, dan hasilnya dapat dijadikan sebagai dasar perbaikan produk sehingga menjadi produk akhir yang memiliki nilai kegunaan, kelayakan, ketepatan, dan kemenarikan yang memenuhi spesifikasi akseptabilitas produk. Analisis data kuantitatif hasil penilaian dan evaluasi yang diperoleh dari instrumen uji ahli BK, ahli materi, ahli media pembelajaran, dan calon pengguna akan dianalisis dengan menggunakan analisis rater yang diusulkan oleh Aiken (1980), yang mana analisis ini digunakan untuk mencari validitas dari produk yang dikembangkan. Adapun kategori indeks kesepakatan rater diinterpretasikan berdasarkan dengan perhitungan penormaan statistik sebagaimana ditunjukkan pada tabel 1.

$$
V=\sum_{i=1}^{c-1} \frac{i n_{i}}{N(c-1)} \ldots \ldots \ldots \ldots \ldots
$$

\section{Keterangan:}

$\begin{array}{ll}\mathrm{V} & \text { : Indeks kesepakatan rater } \\ \mathrm{S} & \text { : Skor yang dipilih rater - skor terendah dalam instrumen } \\ \mathrm{n} & \text { : Jumlah rater } \\ \mathrm{c} & \text { : Banyak kategori yang dipilih rater }\end{array}$


Tabel 1. Kategori Indeks Kesepakatan Rater Usulan Aiken

\begin{tabular}{cc}
\hline Indeks Kesepakata Rater & Kategori Validitas \\
\hline $0,81-1,00$ & Tinggi \\
$0,41-0,80$ & Sedang \\
$0,00-0,40$ & Rendah \\
\hline
\end{tabular}

Data kualitatif yang diperoleh dari saran dan kritik dari ahli diuraikan secara deskriptif dan secara jelas sehingga dapat digunakan sebagai dasar/acuan dalam memperbaiki dan menyempurnakan produk yang dikembangkan.

\section{HASIL}

Berikut adalah hasil penilaian yang diberikan oleh ahli BK, ahli materi, ahli media pembelajaran, dan calon pengguna yang dijabarkan melalui tabel $2-4$.

Tabel 2. Hasil Penilaian Ahli BK

\begin{tabular}{|c|c|c|c|c|c|}
\hline \multirow[t]{2}{*}{ No } & \multirow[t]{2}{*}{ Aspek Penilaian } & \multicolumn{2}{|c|}{ Skor Penilaian } & \multirow[t]{2}{*}{ Indeks Validitas Ahli } & \multirow[t]{2}{*}{ Interpretasi } \\
\hline & & BK1 & BK2 & & \\
\hline \multicolumn{6}{|c|}{ Kegunaan } \\
\hline 1 & $\begin{array}{l}\text { Tingkat relevansi paket pelatihan kesadaran multikultural apabila } \\
\text { diterapkan pada mahasiswa }\end{array}$ & 3 & 3 & 0,67 & Sedang \\
\hline 2 & Faedah pelatihan kesadaran multikultural bagi Dosen & 4 & 3 & 0,83 & Tinggi \\
\hline 3 & Paket pelatihan kesadaran multikultural bernilai penting bagi Dosen & 3 & 3 & 0,67 & Sedang \\
\hline 4 & Faedah pelatihan kesadaran multikultural bagi mahasiswa & 3 & 4 & 0,83 & Tinggi \\
\hline 5 & Paket pelatihan kesadaran multikultural bernilai penting bagi mahasiswa & 4 & 4 & 1 & Tinggi \\
\hline 6 & $\begin{array}{l}\text { Tingkat kejelasan deskripsi langkah membangun rapport pada masing- } \\
\text { masing sesi }\end{array}$ & 3 & 3 & 0,67 & Sedang \\
\hline 7 & $\begin{array}{l}\text { Tingkat kejelasan deskripsi langkah penjelasan tujuan dan gambaran } \\
\text { umum pelatihan. }\end{array}$ & 3 & 3 & 0,67 & Sedang \\
\hline 8 & $\begin{array}{l}\text { Tingkat kejelasan deskripsi langkah permainan (ice breaking) pada } \\
\text { masing-masing sesi. }\end{array}$ & 3 & 3 & 0,67 & Sedang \\
\hline 9 & $\begin{array}{l}\text { Tingkat kejelasan deskripsi langkah pembahasan tugas terkait dengan } \\
\text { komitmen tindakan nyata pada masing-masing sesi yang membahas topik } \\
\text { materi. }\end{array}$ & 4 & 3 & 0,83 & Tinggi \\
\hline 10 & $\begin{array}{l}\text { Tingkat kejelasan deskripsi langkah kegiatan presentasi pada masing- } \\
\text { masing sesi yang membahas topik materi }\end{array}$ & 4 & 3 & 0,83 & Tinggi \\
\hline 11 & $\begin{array}{l}\text { Tingkat kejelasan deskripsi langkah kegiatan praktik pada masing-masing } \\
\text { sesi yang membahas topik materi }\end{array}$ & 3 & 3 & 0,67 & Sedang \\
\hline 12 & $\begin{array}{l}\text { Tingkat kejelasan deskripsi langkah kegiatan dialog pada masing-masing } \\
\text { sesi yang membahas topik materi }\end{array}$ & 3 & 3 & 0,67 & Sedang \\
\hline 13 & $\begin{array}{l}\text { Tingkat kejelasan deskripsi langkah kegiatan penutup pada masing- } \\
\text { masing sesi. }\end{array}$ & 3 & 4 & 0,83 & Tinggi \\
\hline 14 & Tingkat kejelasan materi kesadaran budaya masyarakat global & 3 & 3 & 0,67 & Sedang \\
\hline 15 & Tingkat kejelasan materi kesadaran budaya komunitas & 3 & 3 & 0,67 & Sedang \\
\hline 16 & Tingkat kejelasan materi kesadaran budaya keluarga & 3 & 3 & 0,67 & Sedang \\
\hline 17 & Tingkat kejelasan materi kesadaran budaya diri & 3 & 3 & 0,67 & Sedang \\
\hline 18 & $\begin{array}{l}\text { Tingkat kejelasan lembar kerja mahasiswa pada masing-masing sesi yang } \\
\text { membahas topik materi }\end{array}$ & 3 & 4 & 0,83 & Tinggi \\
\hline 19 & $\begin{array}{l}\text { Besaran dampak penggunaan pelatihan dapat membantu pendidik } \\
\text { konselor dalam menumbuhkan kesadaran multikultural mahasiswa }\end{array}$ & 4 & 3 & 0,83 & Tinggi \\
\hline 20 & $\begin{array}{l}\text { Besaran dampak penggunaan pelatihan dapat membantu mahasiswa dalam } \\
\text { menumbuhkan kesadaran multikulturalnya }\end{array}$ & 3 & 3 & 0,67 & Sedang \\
\hline \multicolumn{6}{|c|}{ Kelayakan } \\
\hline 21 & $\begin{array}{l}\text { Tingkat kemudahan pelaksanaan langkah-langkah dalam paket pelatihan } \\
\text { kesadaran multikultural }\end{array}$ & 4 & 3 & 0,83 & Tinggi \\
\hline 22 & $\begin{array}{l}\text { Tingkat efisiensi jumlah tenaga yang diperlukan untuk melaksanakan } \\
\text { pelatihan kesadaran multikultural }\end{array}$ & 4 & 3 & 0,83 & Tinggi \\
\hline 23 & $\begin{array}{l}\text { Tingkat efisiensi waktu yang diperlukan untuk melaksanakan pelatihan } \\
\text { kesadaran multikultural seperti yang dirancang dalam buku panduan } \\
\text { pelatihan }\end{array}$ & 4 & 3 & 0,83 & Tinggi \\
\hline 24 & $\begin{array}{l}\text { Besaran dampak pengembangan paket pelatihan kesadaran multikultural } \\
\text { ini untuk memilih pendekatan pelatihan yang "cost beneficial" }\end{array}$ & 3 & 3 & 0,67 & Sedang \\
\hline
\end{tabular}


Tabel 2. Hasil Penilaian Ahli BK (Lanjutan)

\begin{tabular}{llccc}
\hline Ketepatan & & & \\
\hline 25 & $\begin{array}{l}\text { Kesesuaian tujuan umum dengan tujuan khusus pelatihan kesadaran } \\
\text { multikultural }\end{array}$ & 4 & 1,00 & Tinggi \\
\hline 26 & $\begin{array}{l}\text { Kesesuaian tujuan pelatihan dengan lembar kerja mahasiswa pada masing- } \\
\text { masing sesi yang membahas topik materi }\end{array}$ & 4 & 1,00 & Tinggi \\
\hline 27 & $\begin{array}{l}\text { Ketepatan langkah-langkah/prosedur pelatihan kesadaran multikultural } \\
\text { apabila diterapkan pada mahasiswa S-1 BK }\end{array}$ & 4 & 0,83 \\
\hline Total Skor Penilaian & 179 & 0,77 & Tinggi \\
\hline
\end{tabular}

Berdasarkan tabel 2 dapat dijelaskan bahwa penilaian kedua ahli bimbingan dan konseling terhadap produk yang dikembangkan pada aspek kegunaan pada item nomor 2, 4, 5, 9, 10, 13, 18, dan 19 memiliki indeks validitas ahli sebesar 1,00 dan termasuk dalam kategori tinggi. Selanjutnya pada item nomor 1, 3, 6, 7, 8, 11, 12, 14, 15, 16, 17 dan 20 memiliki indeks validitas ahli sebesar 0,67 dan termasuk dalam kategori sedang. Selanjutnya penilaian ahli bimbingan dan konseling pada aspek kelayakan pada item nomor 21, 22, dan 23 memiliki indeks validitas ahli sebesar 1,00 dan termasuk dalam kategori tinggi, sedangkan pada item nomor 24 memiliki indeks validitas ahli sebesar 0,67 dan termasuk dalam kategori sedang. Lebih lanjut, penilaian ahli bimbingan dan konseling pada aspek ketepatan pada butir nomor 25, 26, dan 27 memiliki indeks validitas ahli sebesar 1,00 dan termasuk dalam kategori tinggi. Secara keseluruhan, hasil penilaian ahli bimbingan dan konseling terhadap produk yang dikembangkan berdasarkan aspek kegunaan, kelayakan, dan ketepatan diperoleh indeks validitas ahli sebesar 0,77 dan termasuk dalam kategori sedang sehingga dapat disimpulkan produk yang dikembangkan berguna, layak, dan tepat untuk digunakan untuk kegiatan pelatihan.

Tabel 3. Hasil Penilaian Ahli Materi

\begin{tabular}{|c|c|c|c|c|}
\hline No & Aspek Penilaian & Skor Penilaian & Indeks Validitas Ahli & Interpretasi \\
\hline \multicolumn{5}{|c|}{ Ketepatan } \\
\hline 1 & $\begin{array}{l}\text { Semua etnik manusia telah mengalami perkembangan sampai pada tahap } \\
\text { homo sapiens. }\end{array}$ & 4 & 1.00 & Tinggi \\
\hline 2 & Setiap etnik memiliki emosi marah, sedih, senang, gembira, dan cemas. & 4 & 1.00 & Tinggi \\
\hline 3 & $\begin{array}{l}\text { Semua etnik manusia memiliki kesadaran diri, dimana ia mampu untuk } \\
\text { mengetahui, menyadari dan memonitor dunia internalnya. }\end{array}$ & 4 & 1,00 & Tinggi \\
\hline 4 & $\begin{array}{l}\text { Setiap etnik memiliki bahasa tertulis dan bahasa lisan sebagai media } \\
\text { untuk komunikasi. }\end{array}$ & 4 & 1.00 & Tinggi \\
\hline 5 & $\begin{array}{l}\text { Nilai dan tradisi yang berlaku pada suatu komunitas merupakan aspek } \\
\text { budaya yang menunjukan ciri pembeda antara komunitas satu dengan } \\
\text { lainnya. }\end{array}$ & 4 & 1.00 & Tinggi \\
\hline 6 & $\begin{array}{l}\text { Bahasa, dialek, baju adat, tari-tarian dan prosesi pemakaman merupakan } \\
\text { bagian dari tradisi yang berlaku dalam suatu komunitas. }\end{array}$ & 4 & 1,00 & Tinggi \\
\hline 7 & $\begin{array}{l}\text { Nilai dan tradisi yang berlaku pada suatu keluarga merupakan aspek } \\
\text { budaya yang menunjukan ciri pembeda antara keluarga satu dengan } \\
\text { lainnya. }\end{array}$ & 4 & 1,00 & Tinggi \\
\hline 8 & $\begin{array}{l}\text { Gambaran umum, komunikasi, keluarga, ekologi biokulktural, perilaku } \\
\text { beresiko tinggi, nutrisi, kematian, spiritual dan kesehatan merupakan } \\
\text { domain budaya yang menunjukkan ciri pembeda antara individu satu } \\
\text { dengan lainnya. }\end{array}$ & 3 & 0,67 & Sedang \\
\hline 9 & $\begin{array}{l}\text { Setiap individu berbeda satu sama lain, meskipun lahir, tumbuh dan } \\
\text { berkembang dalam lingkungan yang sama. }\end{array}$ & 4 & 1,00 & Tinggi \\
\hline 10 & $\begin{array}{l}\text { Ketepatan antara tugas dengan isi materi yang diberikan pada setiap } \\
\text { pertemuan }\end{array}$ & 3 & 0,67 & Sedang \\
\hline 11 & Kejelasan materi budaya masyarakat global & 4 & 1,00 & Tinggi \\
\hline 12 & Kejelasan materi budaya komunitas & 4 & 1,00 & Tinggi \\
\hline 13 & Kejelasan materi budaya keluarga & 4 & 1,00 & Tinggi \\
\hline 14 & Kejelasan materi budaya diri & 4 & 1,00 & Tinggi \\
\hline 15 & $\begin{array}{l}\text { Kesesuaian ilustrasi/cerita dengan topik bahasan pada materi budaya } \\
\text { masyarakat global }\end{array}$ & 3 & 0,67 & Sedang \\
\hline 16 & $\begin{array}{l}\text { Kesesuaian ilustrasi/cerita dengan topik bahasan pada materi budaya } \\
\text { komunitas dan keluarga }\end{array}$ & 3 & 0,67 & Sedang \\
\hline 18 & Kesesuaian ilustrasi/cerita dengan topik bahasan pada materi budaya diri & 3 & 0,67 & Sedang \\
\hline 19 & $\begin{array}{l}\text { Kesesuaian gambar yang disajikan dengan materi pelatihan pada setiap } \\
\text { pertemuan }\end{array}$ & 4 & 1,00 & Tinggi \\
\hline Tot & I Skor Penilaian Ahli Materi & 70 & 0,89 & Tinggi \\
\hline
\end{tabular}


Berdasarkan tabel 3 dapat dijelaskan bahwa penilaian ahli pada butir nomor 1, 2, 3, 4, 5, 6, 7, 9, 11, 12, 13, 14 dan 19 memiliki indeks validitas ahli sebesar 1,00 dan termasuk dalam kategori tinggi. Selanjutnya, pada butir nomor 8, 10, 15, 16, 17, dan 18 memiliki indeks validitas ahli sebesar 0,67 dan termasuk dalam kategori sedang. Secara keseluruhan hasil penilaian ahli materi terhadap produk yang dikembangkan berdasarkan aspek ketepatan materi diperoleh indeks validitas ahli sebesar 0,89 dan termasuk dalam kategori tinggi sehingga dapat disimpulkan materi pelatihan yang dikembangkan sudah tepat dan baik sehingga dapat digunakan sebagai materi dalam pelatihan.

Tabel 4. Hasil Penilaian Ahli Media Pembelajaran

\begin{tabular}{|c|c|c|c|c|}
\hline No & Aspek Penilaian & Skor Penilaian & Indeks Validitas Ahli & Interpretasi \\
\hline \multicolumn{5}{|c|}{ Kemenarikan } \\
\hline 1 & Kemenarikan sampul buku paket pelatihan kesadaran multikultural & 3 & 0,67 & Sedang \\
\hline 2 & $\begin{array}{l}\text { Kemenarikan warna sampul buku paket pelatihan kesadaran } \\
\text { multikultural }\end{array}$ & 4 & 1.00 & Tinggi \\
\hline 3 & $\begin{array}{l}\text { Kemenarikan desain sampul buku paket pelatihan kesadaran } \\
\text { multikultural }\end{array}$ & 4 & 1,00 & Tinggi \\
\hline 4 & Kemenarikan desain penyajian materi & 3 & 0,67 & Sedang \\
\hline 5 & $\begin{array}{l}\text { Kemenarikan jenis huruf yang digunakan pada buku paket pelatihan } \\
\text { kesadaran multikultural }\end{array}$ & 3 & 0,67 & Sedang \\
\hline 6 & $\begin{array}{l}\text { Kemenarikan halaman isi pada buku paket pelatihan kesadaran } \\
\text { multikultural }\end{array}$ & 4 & 1,00 & Tinggi \\
\hline \multicolumn{5}{|c|}{ Ketepatan } \\
\hline 7 & Keterbacaan tulisan pada sampul & 4 & 1,00 & Tinggi \\
\hline 8 & Keterbacaan tabel yang disajikan & 4 & 1,00 & Tinggi \\
\hline 9 & Keterbacaan teks materi & 4 & 1,00 & Tinggi \\
\hline 10 & Kejelasan penulisan istilah non indonesia & 4 & 1,00 & Tinggi \\
\hline 11 & Kejelasan penggambaran isi buku paket dalam daftar isi & 4 & 1,00 & Tinggi \\
\hline 12 & Ketepatan tata letak penyajian tabel & 4 & 1,00 & Tinggi \\
\hline 13 & Ketepatan pemenggalan tabel pada halaman berikutnya & 3 & 0,67 & Sedang \\
\hline 14 & Ketepatan penulisan daftar rujukan & 4 & 1,00 & Tinggi \\
\hline Tot & I Skor Penilaian & 52 & 0,90 & Tinggi \\
\hline
\end{tabular}

Berdasarkan tabel 4 dapat dijelaskan bahwa penilaian ahli pada item nomor 2, 3, 6, 7, 8, 9, 10, 11, 12, dan 14 memiliki indeks validitas ahli sebesar 1,00 dan termasuk dalam kategori tinggi. Selanjutnya pada item nomor 1, 4, 5 dan 13 memiliki indeks validitas ahli sebesar 0,67 dan termasuk dalam kategori sedang. Secara keseluruhan hasil penilaian ahli media pembelajaran terhadap produk yang dikembangkan berdasarkan aspek kemenarikan dan ketepatan diperoleh indeks validitas ahli sebesar 0,90 dan termasuk dalam kategori tinggi, sehingga dapat disimpulkan produk yang dikembangkan menarik dan dapat digunakan dengan baik sebagai media pembelajaran.

Berdasarkan hasil analisis data kuantitatif melalui sebaran angket penilaian produk yang dikembangkan terhadap ahli bimbingan dan konseling, ahli materi, ahli media pembelajaran, maka dapat disimpulkan bahwa produk yang dikembangkan telah memenuhi kriteria kegunaan, kelayakan, ketepatan, dan kemenarikan sehingga produk yang dikembangkan dapat digunakan dalam kegiatan pelatihan.

Tabel 5. Hasil Penilaian Calon Pengguna

\begin{tabular}{|c|c|c|c|c|c|}
\hline \multirow[t]{2}{*}{ No } & \multirow[t]{2}{*}{ Aspek Penilaian } & \multicolumn{2}{|c|}{ Skor Penilaian } & \multirow[t]{2}{*}{ Indeks Validitas Ahli } & \multirow[t]{2}{*}{ Interpretasi } \\
\hline & & CP1 & CP2 & & \\
\hline \multicolumn{6}{|c|}{ Kegunaan } \\
\hline 1 & $\begin{array}{l}\text { Tingkat relevansi paket pelatihan kesadaran multikultural apabila } \\
\text { diterapkan pada mahasiswa }\end{array}$ & 3 & 3 & 0,67 & Sedang \\
\hline 2 & Faedah pelatihan kesadaran multikultural bagi Dosen & 3 & 3 & 0,67 & Sedang \\
\hline 3 & Paket pelatihan kesadaran multikultural bernilai penting bagi Dosen & 3 & 4 & 0,83 & Tinggi \\
\hline 4 & Faedah pelatihan kesadaran multikultural bagi mahasiswa & 4 & 4 & 1,00 & Tinggi \\
\hline 5 & $\begin{array}{l}\text { Paket pelatihan kesadaran multikultural bernilai penting bagi } \\
\text { mahasiswa }\end{array}$ & 4 & 4 & 1,00 & Tinggi \\
\hline 6 & $\begin{array}{l}\text { Tingkat kejelasan deskripsi langkah membangun rapport pada masing- } \\
\text { masing sesi }\end{array}$ & 4 & 4 & 1,00 & Tinggi \\
\hline 7 & $\begin{array}{l}\text { Tingkat kejelasan deskripsi langkah penjelasan tujuan dan gambaran } \\
\text { umum pelatihan. }\end{array}$ & 4 & 4 & 1,00 & Tinggi \\
\hline
\end{tabular}


Tabel 5. Hasil Penilaian Calon Pengguna (Lanjutan)

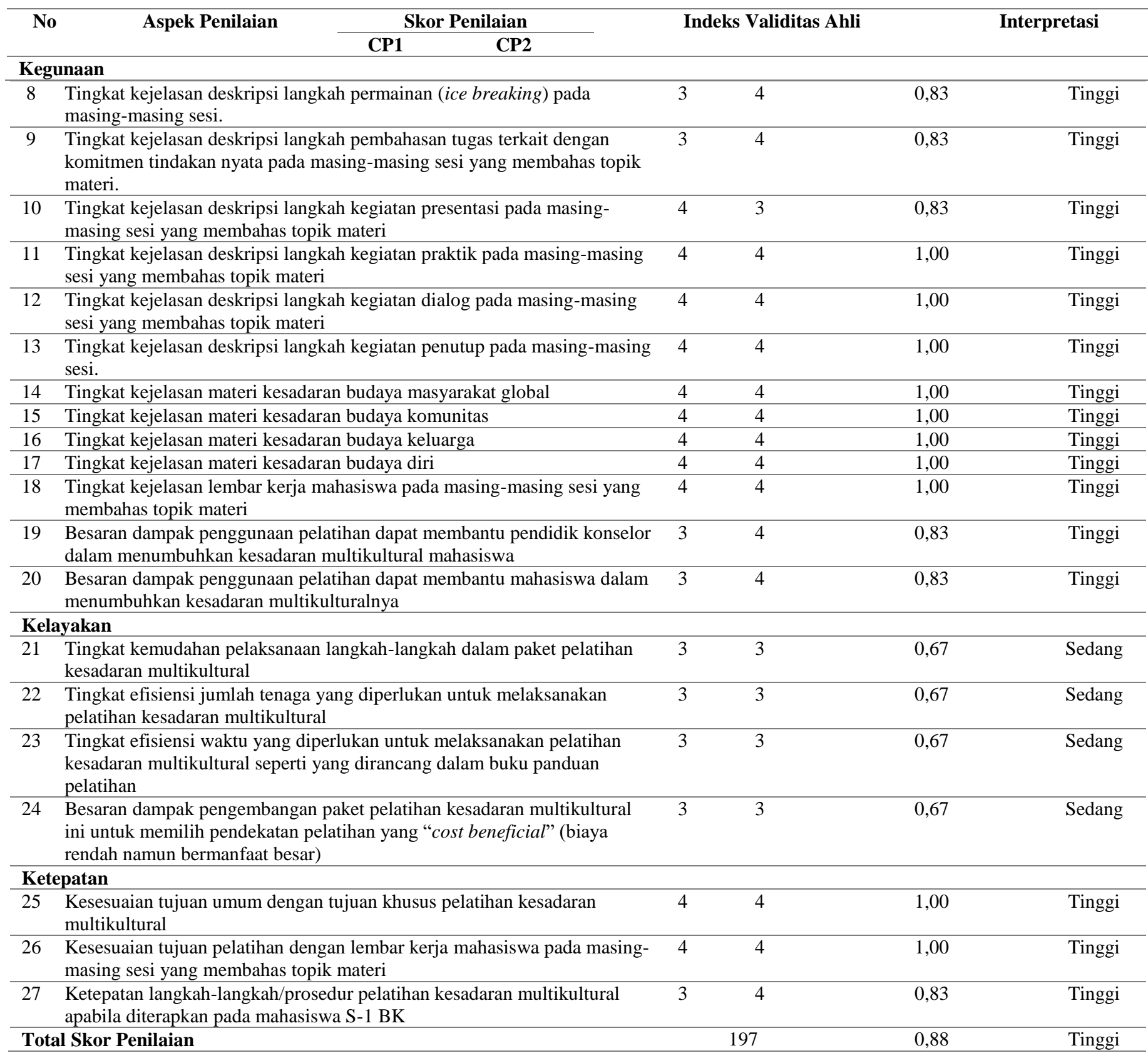

Berdasarkan tabel 5 dapat dijelaskan bahwa penilaian ahli bimbingan dan konseling terhadap produk yang dikembangkan pada aspek kegunaan pada butir nomor 3, 4, 5, 6, 7, 8, 9, 10, 11, 12, 13, 14, 15, 16, 17, 18, 19, dan 20 memiliki indeks validitas ahli sebesar 1,00 dan termasuk dalam kategori tinggi. Pada butir nomor 1 dan 2 memiliki indeks validitas ahli sebesar 0,67 dan termasuk dalam kategori sedang. Penilaian ahli bimbingan dan konseling pada aspek kelayakan pada butir nomor 21, 22, 23, dan 24 memiliki indeks validitas ahli sebesar 0,67 dan termasuk dalam kategori sedang. Lebih lanjut, penilaian ahli bimbingan dan konseling pada aspek ketepatan pada item nomor 25, 26, dan 27 memiliki indeks validitas ahli sebesar 1,00 dan termasuk dalam kategori tinggi. Secara keseluruhan, hasil penilaian calon pengguna terhadap produk yang dikembangkan berdasarkan aspek kegunaan, kelayakan, dan ketepatan diperoleh indeks validitas sebesar 0,88 dan termasuk dalam kategori tinggi sehingga dapat disimpulkan produk yang dikembangkan berguna, layak, dan tepat untuk digunakan dalam kegiatan pelatihan. 


\section{PEMBAHASAN \\ Pembahasan Hasil Uji Ahli BK}

Hasil analisis data kuantitatif penilaian ahli BK sebagaimana yang telah diuraikan dalam hasil penelitian menunjukkan indeks validitas ahli terhadap produk diperoleh sebesar 0,77 dan termasuk dalam kategori sedang sehingga dapat disimpulkan bahwa produk yang dikembangkan berguna, layak, dan tepat, hal ini didasarkan akan kebutuhan pendidik konselor dalam upaya mengembangkan kualitas pirbadi calon konselor sekolah (Depdiknas, 2007). Selain itu, metode yang digunakan dalam pelatihan menitikberatkan aspek konstruktivistik yang sesuai atas rancangan Kurikulum 2013.

Pelatihan diawali dengan presentasi, yaitu penyajian materi pelatihan. Penyajian materi ini dimaksudkan untuk memberikan informasi agar mahasiswa semakin memahami adanya keberagaman budaya. Tahapan yang kedua ialah kegiatan praktik yang diberikan dalam bentuk pemberian tugas yaitu melakukan eksplorasi terkait budaya dari narasumber yang dihadirkan. Praktik dimaksudkan memberikan pengalaman nyata bagi mahasiswa untuk lebih mengenal dan memahami budaya yang anut oleh narasumber. Asumsi ini didukung oleh pendapat Kolb (dalam Chong, 2016) bahwa pembelajaran berbasis pengalaman dapat membantu pembelajar dalam mengembangkan pemahaman otentik mereka tentang materi pelajaran. Kegiatan selanjutnya ialah dialog yang terwujud dengan aktivitas diskusi dan dilanjutkan dengan refleksi pengalaman belajar yang dialami mahasiswa. Dialog memberikan ruang bagi peserta untuk menyampaikan perubahan yang dialami selama mengikuti kegiatan dan refleksi diri. Refleksi diri akan membuka mata hati dan pikiran mahasiswa dalam menilai segala tindakannya yang mungkin tidak produktif dan menemukan sejumlah kekeliruan yang perlu diperbaiki (Akhmadi, 2013).

Berdasarkan kajian di atas dapat disimpulkan bahwa paket pelatihan kesadaran multikultural telah memenuhi kriteria keberterimaan produk yang mencangkup aspek kegunaan, kelayakan, dan ketepatan yang dikembangkan oleh Joint Committee on Standards for Educational Evaluations (1981). Paket pelatihan kesadaran multikultural ini diharapkan dapat menjadi jawaban dan terobosan baru dalam upaya meningkatkan kesadaran muktikultural mahasiswa.

\section{Pembahasan Hasil Uji Ahli Materi}

Materi pelatihan disusun berdasarkan skema lingkaran model Purnell (2014). Hal ini didasarkan pada kerangka pengorganisasian yang termuat dalam skema budaya dipandang sebagai konstruk yang tepat untuk dijadikan sebagai materi pelatihan karena telah memuat kerangka budaya yang kompleks yang terdiri dari budaya masyarakat global, budaya komunitas, budaya keluarga, dan budaya diri berserta domain budaya didalamnya. Materi pelatihan dipandang sangat tepat oleh ahli materi, hal ini ditunjukkan dengan hasil uji coba untuk menilai kebenaran isi materi yang mencakup aspek ketetapan dan kelayakan materi pelatihan melalui instrumen penilaian ahli materi. Hasil analisis data kuantitatif sebagaimana yang telah diuraikan di bab IV menunjukkan indeks validitas ahli terhadap materi pelatihan diperoleh sebesar sebesar 0,89 dan termasuk dalam kategori tinggi. Hasil ini diperkuat dengan adanya pengakuan yang diberikan oleh Leininger (dalam Purnell, 2002) bahwa variabelvariabel budaya yang terdapat dalam model Purnell diperlukan untuk menilai budaya.

\section{Kajian Hasil Uji Ahli Media Pembelajaran}

Paket pelatihan kesadaran multikultural disusun dalam sebuah buku panduan sebagai media pembelajaran. Sampul luar paket pelatihan kesadaran multikultural diilustrasikan dengan menggunakan gambar kepala seorang pemuda yang mengartikan kesadaran. Kemudian gambar keberagaman budaya seperti bendera Negara, wajah, pakaian adat, agama, warna kulit, dan rumah adat. Seluruh gambar tersebut mengilustrasikan keberagaman budaya yang dilihat dari berbagai aspek sehingga ilustrasi melalui gambar pada sampul depan paket pelatihan telah memuat makna kesadaran multikultural. Pemilihan warna juga menjadi fokus dalam mendesain cover. Warna biru dipilih untuk memberikan kesan kenyamanan dan ketenangan bagi pembaca. Selanjutnya, penentuan warna teks dalam cover depan harus kontras agar memudahkan pembaca membaca teks yang dituliskan, hal ini sejalan dengan pendapat Prastowo (2012) bahwa warna teks harus kontras dengan warna latar agar dapat terbaca dan terfokus dengan jelas pada pesan yang ingin disampaikan.

Bagian isi paket pelatihan kesadaran multikultural didesain dengan memperhatikan jenis huruf, ukuran huruf, dan gambar dalam buku panduan. Jenis huruf yang digunakan ialah Georgia dengan ukuran huruf 11 poin dan spasi 1,5. Pertimbangan utama penentuan jenis, ukuran, dan spasi dalam penulisan ialah nilai keterbacaan dan kenyamanan saat dibaca. Penyususan panduan paket pelatihan ini telah sesuai dan telah memenuhi syarat ketentuan BSNP yang tertuang dalam Peraturan Pemerintah Nomor 19 Tahun 2005 tentang Standar Nasional Pendidikan (2005).

Berdasarkan hasil analisis data kuantitatif sebagaimana yang telah diuraikan di bab IV menunjukkan indeks validitas ahli terhadap produk paket pelatihan kesadaran multikultural diperoleh nilai sebesar 0,90 dan termasuk dalam kategori tinggi sehingga dapat disimpulkan bahwa produk paket pelatihan kesadaran multikultural telah memenuhi kriteria kemenarikan dan ketepatan untuk dijadikan media pembelajaran. 


\section{Pembahasan Hasil Uji Calon Pengguna}

Uji coba calon pengguna produk melibatkan dua orang subjek, dimana masing-masing calon pengguna memberikan penilaian terhadap produk yang mencangkup aspek kegunaan, kelayakan, dan ketepatan. Secara umum, kedua calon pengguna menilai uraian yang dijelaskan dalam panduan sudah sangat jelas dan baik. Hal ini selaras dengan hasil penilaian kedua calon pengguna berdasarkan instrumen penilaian, dimana diperoleh indeks validitas sebesar 0,88 dan termasuk dalam kategori tinggi, sehingga dapat disimpulkan produk yang dikembangkan berguna, layak, dan tepat untuk digunakan dalam kegiatan pelatihan.

\section{SIMPULAN}

Hasil pengujian keberterimaan produk oleh ahli bimbingan dan konseling, ahli materi, ahli media pembelajaran, dan calon pengguna menunjukkan bahwa paket pelatihan kesadaran multikultural telah memenuhi kriteria akseptabilitas produk yang mencakup aspek kegunaan, kelayakan, ketepatan, dan kemenarikan sehingga produk paket pelatihan kesadaran multikultural layak digunakan dalam kegiatan pelatihan untuk menguji keefektifan produk.

Adapun saran-saran yang dapat diberikan bagi peneliti lain dan dosen. Pertama, bagi peneliti selanjutnya diharapkan dapat melanjutkan langkah pengujian keefektifan produk pada skala luas sehingga diperoleh keterbatasan produk untuk kemudian diperbaiki. Kedua, bagi dosen. Terkait dengan alokasi waktu pelaksanaan pelatihan sebagaimana yang telah dijelaskan dalam buku panduan, dosen/pelatih dapat melaksanakan kegiatan pelatihan di luar jam perkuliahan.

\section{DAFTAR RUJUKAN}

Aiken, L. (1980). Content Validity and Reliability of Single Items or Questionaires. Educational and Psychological Measurement, 40, 955-967.

Akhmadi, A. (2013). Peningkatan Kesadaran Multikultural Konselor (Guru BK). MUADDIB, 3(2), 18-36.

Chong, E. K. M. (2016). Teaching Global Citizenship Education with Empathy Model and Experiential Learning: Case Study of Action Research on Developing Empathy in a Hong Kong Secondary School. In Educating for the $21^{\text {st }}$ Century: Perspectives, Policies and Practices from Around the World. https://doi.org/10.1007/978-981-10-1673-8_16

Depdiknas. (2007). Naskah Akademik Penataan Pendidikan Profesional Konselor dan Layanan Bimbingan dan Konseling dalam Jalur Pendidikan Formal. Jakarta: Direktorat Jenderal Pendidikan Tinggi.

Gumilang, G. . (2015). Urgency Cultural Awareness Skills of Counselors in Implementing The Service Guidance and Counseling For Dealing Asean Economic Community (AEC). Jurnal Guidena, 5(2), 45-58.

Hambali, I. (2016). Model Dialog “4D” untuk Meningkatkan Kesadaran Multi-Kultural Siswa SMA di Kota Malang. Jurnal Kajian Bimbingan Dan Konseling, 1(3), 95-103. https://doi.org/10.17977/um001v1i32016p095

Ivey. (2010). Intentional Interviewing and Counseling: Facilitating Client Development in a Multicultural Society, Seven Edition (Brooks/Cole, ed.). USA.

Joint Committee on Standards for Educational Evaluations. (1981). The Program Evaluation Standards: How to Assess Evaluations of Educational programs. https://doi.org/10.4135/9781412950558.n446

Modood, T. (2017). Must Interculturalists Misrepresent Multiculturalism? Comparative Migration Studies, 5-15. https://doi.org/10.1186/s40878-017-0058-y

Moule, J. (2012). Cultural Competence: A Primer for Educators. Second Edition. USA: Wadsworth.

Permatasari, D., Bariyyah, K., \& Indrati, E. N. (2017). Tingkat Kesadaran Multikultural dan Urgensinya dalam Bimbingan dan Konseling. Jurnal Konseling Indonesia, 2(1), 22-28.

Prastowo, A. (2012). Panduan Kreatif Membuat Bahan Ajar Inovatif. Yogyakarta: DIPA Press.

Purnell, L. (2002). The Purnell Model for Cultural Competence. Journal of Transcultural Nursing, 13, $193-196$. https://doi.org/10.1177/10459602013003006

Purnell, L. (2005). The Purnell Model for Cultural Competence. Journal of Transcultural Nursing, 11(2). https://doi.org/10.1177/10459602013003006

Ratts, M. J., \& Pedersen, P. B. (2014). Counseling for Multiculturalism and Social Justice: Integration, Theory, and Application (4th ed.). USA: American Counseling Association.

Rohiman, I., \& Pamuji, R. (2017). Pengembangan Kesadaran Multibudaya bagi Calon Konselor di Era Globalisasi. Prosiding Seminar Nasional Peran Bimbingan dan Konseling Dalam Penguatan Pendidikan Karakter Universitas Ahmad Dahlan 2017, 109-116.

Vora, D., Martin, L., Fitzsimmons, S. R., Pekerti, A. A., Lakshman, C., \& Raheem, S. (2018). Multiculturalism within Individuals: A Review, Critique, and Agenda for Future Research. Journal of International Business Studies. https://doi.org/10.1057/s41267-018-0191-3

Zapata-Barrero, R. (2018). Rejoinder: Multiculturalism and Interculturalism: Alongside but Separate. Comparative Migration Studies, 6(20), 1-12. https://doi.org/10.1186/s40878-018-0090-6 